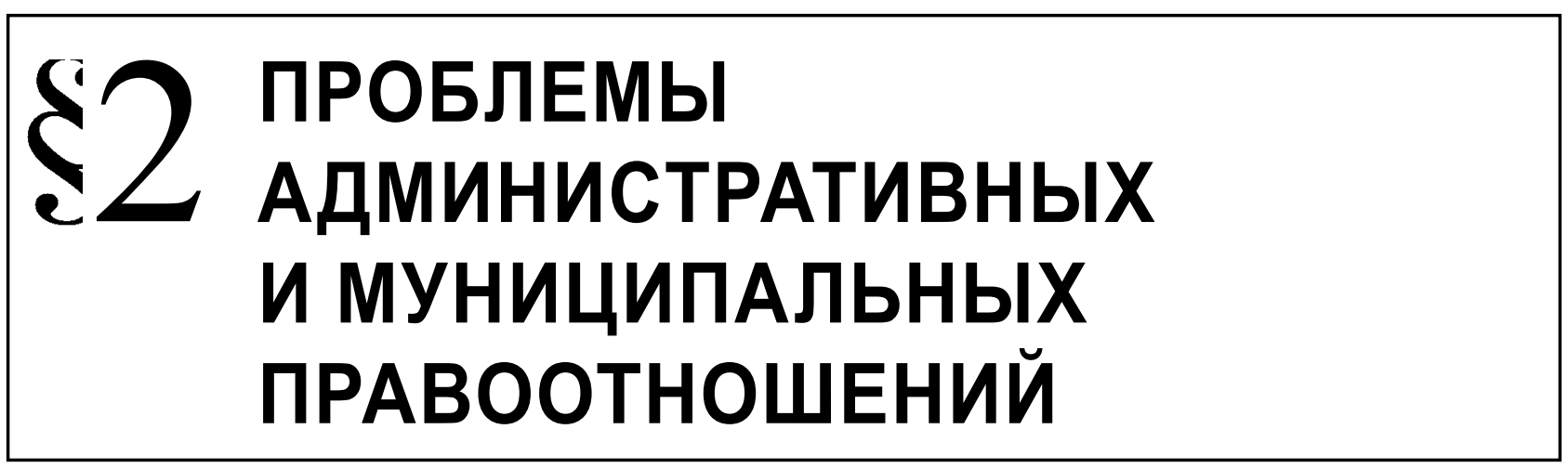

Павлюк А.В.

\title{
К ВОПРОСУ О ПОНЯТИИ АКЦИОНЕРНОГО ОБЩЕСТВА В РОССИЙСКОМ ПРАВЕ
}

Аннотация: Совершенствование административного законодательства, регламентирующего деятельность акционерных обществ, должно осуществлять на основе учета норм, действующих в государствах Европейского союза, а вступление Российской Федерации во Всемирную торговую организацию и Европейский экономический союз диктует необходимость развития и укрепления административно-правового статуса акционерных обществ. В настоящее время существует потребность в более четком определении такой категории, как коллективный субъект административного права, а также разработке системы эффрективных административно-правовых средств воздействия на деятельность непосредственно акционерных обществ. Методологическую основу статьи составили современные достижения теории познания. В процессе исследования применялись общефилософский, теоретический, общефилософские методы (диалектика, системный метод, анализ, синтез, аналогия, дедукция, наблюдение, моделирование), традиционно правовые методы (формально-логический), а также методы, используемые в конкретносоциологических исследованиях (статистические, экспертные оценки и др.). Выявление существенных и отличительных особенностей, характеризующих акционерные общества, рассмотрение характерных признаков акционерных обществ, как юридических лиц, анализ существующих способов управления деятельностью акционерных обществ и присущих данным способам недостатков, позволит более глубоко изучить "Административно-правовое регулирование деятельности акционерных обществ».Процесс административно-правового регулирования предполагает существование двух сторон: субъекта правового регулирования и объекта правового регулирования.

Ключевые слова: управление, общество, акция, акционер, статус, ценная, бумага, регулирование, метод, государство.

3 начение акционерных обществ в экономике любого государства достаточно велико. Как отмечал в свое время И. Соколов «...вполне понятно, что на предприятиях, внедряющих акционерные отношения, выше производительность труда, производственная и трудовая дисциплина. Вот почему использование акционерной формы является эффективным способом решения проблемы убыточных государственных предприятий»1. Акционерная форма объединения капитала пред-

1 См.: Соколов И. Акционерные общества и экономическая реформа // Советская юстиция. - 1990. - № 2. - С. 21. ставляет собой наиболее совершенный правовой механизм по организации экономики на основе объединения имущества юридических и физических лиц. Акционерное общество в государстве с рыночной экономикой выполняет функцию объединения капиталов, причем не только денежных, но и имущественных средств².

\footnotetext{
2 На основании п.2 ст. 34 Ф3 «Об акционерных обществах» Оплата акций, распределяемых среди учредителей общества при его учреждении, дополнительных акций, размещаемых посредством подписки, может осуществляться деньгами, ценными бумагами, другими вещами или имущественными
} 
Еще в 1867 г. Карл-Маркс отметил, что «...мир до сих пор остался бы без железных дорог, если бы приходилось дожидаться, пока накопление не доведет некоторые капиталы до таких размеров, что они могли бы справиться с постройкой железных дорог. Напротив, централизация посредством акционерных обществ осуществила это в один миг» ${ }^{3}$.

Изучение особенностей акционерных обществ, как объекта административно-правового регулирования, актуально как в теоретическом, так и практическом плане, поскольку позволяет выявить существенные недостатки в реализации правовых норм, регулирующих соответствующие общественные отношения и на базе проведенного анализа выработать наиболее эффективные способы совершенствования действующего законодательства.

Анализ преимуществ акционерных обществ, по сравнению с другими организационно-правовыми формами, выявление существенных и отличительных особенностей, характеризующих акционерные общества, рассмотрение характерных признаков акционерных обществ, как юридических лиц, анализ существующих способов управления деятельностью акционерных обществ и присущих данным способам недостатков, позволит более глубоко изучить «Административно-правовое регулирование деятельности акционерных обществ».

Процесс административно-правового регулирования предполагает существование двух сторон: субъекта правового регулирования и объекта правового регулирования. В нашем исследовании объектом административно-правового регулирования выступают акционерные общества.

Акционерные общества вступают в административные правоотношения в процессе их создания при осуществлении коммерческой деятельности, при исполнении публичных обязанностей, а также в случае совершения правонарушений. Возникновение общих административных правоотношений обусловлено наделением акционерного общества правами и обязанностями коммерческой

правами либо иными правами, имеющими денежную оценку. Форма оплаты акций общества при его учреждении определяется договором о создании общества, дополнительных акций - решением об их размещении. Оплата иных эмиссионных ценных бумаг может осуществляться только деньгами. Устав общества может содержать ограничения на виды имущества, которым могут быть оплачены акции общества.

3 См.: Маркс К., Энгельс Ф. Сочинения. 2-е издание. Т.23. C. 642 . организации. Особая роль акционерного общества, как объекта акционерного правоотношения, требует тщательного анализа его правового статуса. Но перед этим необходимо отметить, что акционерные правоотношения, носят имущественный характер, в то же время эти отношения не являются вещными, ибо участники акционерного общества, передавая свое имущество в обмен на членские права, теряют на него право собственности ${ }^{4}$.

Среди ученых, внесших свой вклад в разработку проблем акционерного права, в исследование юридической природы акционерных компаний, как объекта правового регулирования, порядка их создания и особенностей функционирования, можно назвать Л.И. Петражицкого, И.Т. Тарасова, А.И. Каминку, С.Н. Ландкофа, В.С. Зив, И.М. Кулишера, А.Г. Тимофеева, В.Е. Белинского, А.М. Гуляева, А.С. Лаппо-Данилевского, И.Л. Брауде, В.Ю Вольф, М.Н. Израэлит 5 .

Различные аспекты правового регулирования деятельности акционерных обществ исследовались в работах современных российских ученыхюристов: В.В. Долинской, В.А. Белова, М.Г. Ионцева, И.С. Шиткиной, Е.А. Суханова, Т.В. Кашаниной, О.А. Макаровой и др. ${ }^{6}$

4 См. : Ломакин Д.В. Акционерное правоотношение. - М., 1997. - C. 19.

5 См.: Петражицкий Л.И. Акционерная компания. Акционерные злоупотребления и роль акционерных компаний в народном хозяйстве. - СПб., 1898; Тарасов И.Т. Учение об акционерных компаниях. - М., 2000; Каминка А.И. Акционерные компании. Юридическое исследование. - СПб., 1912. Т.1.; Ландкоф С.Н. Проблема развития акционерного права. - Харьков, 1927; Зив, В. С. Иностранные капиталы в русских акционерных предприятиях. Германские капиталы. Вып. 1. - Пг., 1915.; Кулишер И. М. История русской торговли и промышленности. - Челябинск, 2003; Белинский B.Е. Эволюция учреждения акционерных товариществ. Образование акционерного товарищества согласно современному праву. - СПб., 1903; Гуляев А.М. Русское гражданское право. - СПб., 1913; Лаппо-Данилевский А.С. Русские промышленные и торговые компании в первой половине XVIII столетия. - СПб.,1899; Брауде И. Л. Акционерные общества и товарищества в торговле и промышленности. - Пг., 1923; Вольф В. Ю. Основы учения о товариществах и акционерных обществах. - М., 1927; Израэлит М. Н. Акционерные общества. - М., 1927 и др.

6 См.: Долинская В.В. Акционерное право. Основные положения и тенденции. - М., 2006; Белов В.А. Корпоративное право: актуальные проблемы теории и практики. - М., 2009; Ионцев М.Г. Акционерные общества. - М., 2007; Шиткина И.С. Корпоративное право. - М., 2008; Суханов Е.А. Гражданское право. - М., 2004; Кашанина Т.В. Корпоративное право (Право хозяйственных товариществ и обществ). М.,1999; Макарова О.А. Корпоративное право. - М., 2005. 
Правовую основу организации и деятельности акционерных обществ составляет Федеральный Закон от 26 декабря 1995 г. «Об акционерных обществах» (далее Закон «Об акционерных обществах) 7 . В п. 1 ст. 2 Закона «Об акционерных обществах» акционерное общество определяется, как «коммерческая организация, уставный капитал которой разделен на определенное число акций, удостоверяющих обязательственные права участников общества (акционеров) по отношению к обществу».

В п.1 ст.96 Гражданского кодекса Российской Федерации от 30 ноября 1994 г., под акционерным обществом понимается «общество, уставный капитал которого разделен на определенное число акций. Участники акционерного общества (акционеры) не отвечают по его обязательствам и несут риск убытков, связанный с деятельностью общества, в пределах стоимости принадлежащих им акций» ${ }^{8}$.

Проанализировав легальные определения понятия «акционерное общество», можно отметить, что в них содержатся противоречия, как внутренние, так и противоречия с другими нормами права. Здесь важно сказать, что как и у любого хозяйственного общества, уставный капитал акционерного общества (состоящий из номинальной стоимости акций) делится не на акции, ${ }^{9}$ а на равные доли стоимостного выражения суммы вкладов акционеров (п.1 ст. 66 ГК РФ, п.1 ст. 25 Закона «Об акционерных обществах»).

Как отмечают некоторые авторы, при всей расплывчатости и явной уязвимости законодательной формулировки «акционерного общества», четко прослеживается сама суть данного понятия и проводится разграничительная черта с другими организационно-правовыми формами предпринимательства ${ }^{10}$.

В научной литературе можно встретить и другие понятия акционерного общества. Так, например, А.И. Каминка определил акционерное общество, как «корпоративный союз лиц (акционеров), обра-

\footnotetext{
См.: Собрание законодательства РФ. - 1996. - № 1. - Ст. 1. 8 См.: Собрание законодательства РФ. - 1994. - № 32. Ст. 3301.

9 В ч. 2, ст.2 Ф3 «О рынке ценных бумаг» Акция - эмиссионная ценная бумага, закрепляющая права ее владельца (акционера) на получение части прибыли акционерного общества в виде дивидендов, на участие в управлении акционерным обществом и на часть имущества, остающегося после его ликвидации. Акция является именной ценной бумагой.

10 См.: Мамай В.И. К понятию и признакам акционерного общества // Государство и право. - 1996. - № 11. - С.20.
}

зовавших его капитал путем определенного числа равных (нормально свободно отчуждаемых) взносов, которые дают право на участие в союзе и которыми исчерпываются обязанности акционеров» ${ }^{11}$.

Г.Ф. Шершеневичем было дано следующее понятие: «акционерное товарищество, есть основанное на договоре соединение лиц с целью совместного производства торгового промысла, при помощи капитала, разделенного на равного размера доли, пределами которых и ограничивается ответственность каждого участника» ${ }^{12}$.

В.А. Шаницын пишет, что «акционерное общество - это организационно-правовая форма предприятия, которое отвечает по своим обязательствам только принадлежащим ему имуществом» ${ }^{13}$.

А.И. Андрющенко, Е.В. Костикова под акционерным обществом понимают «одну из организационно-правовых форм предприятий, создающихся путем централизации денежных средств (объединения капиталов) различных лиц, проводимой посредством продажи акций» ${ }^{14}$.

Из приведенных легальных и научных определений можно выделить существенные и отличительные признаки, характеризующие акционерное общество.

1. Акционерное общество является формой хозяйственного общества.

2. Акционерное общество может быть только коммерческой организацией. Следовательно, некоммерческая организация, по своей организационно правовой форме, не может быть акционерным обществом.

3. Акционерным обществом признается хозяйственное общество, уставный капитал которого разделен на доли (один из признаков хозяйственных обществ - п.1 ст.66 ГКРФ) равного размера (номинальная стоимость всех обыкновенных акций общества должна быть одинаковой - ч.II п.1 ст. 25 Ф3 «Об акционерных обществах»), каждая из которых получает выражение в акции.

4. Акционерное общество формирует свой капитал за счет эмиссии акций.

5. Доли участия в уставном капитале воплоща-

\footnotetext{
11 См.: Каминка А.И. Акционерные компании. Юридическое исследование. - СПб., 1902. - Т.1. С. 14.

12 См.: Шершеневич Г.Ф. Курс торгового права. Т.1. - СПб., 1908. - C.383.

13 См.: Пособие для международного предпринимателя / Под. ред. В.А. Шаницына. - Краснодар, 1990. - С.78

14 См.: Андрющенко В.И., Костикова Е.В. Книга акционера для чтения и принятия решений. - М., 1994. - С. 8.
} 
ются в специальные ценные бумаги - акции, из номинальной стоимости которых составляется этот капитал, являющийся обособленным имуществом.

6. Приобретая акции, между обществом и акционером возникают не вещные, а обязательственные отношения ${ }^{15}$. Акционер получает право на управление обществом, получение доходов от деятельности общества, а также на часть имущества, оставшегося после ликвидации общества. Имущество ${ }^{16}$ акционерного общества принадлежит только обществу, а акционерам - лишь акции, дающие соответствующие права, исключая права на имущество общества. Это означает, что акционер не может вернуть обществу свои акции и потребовать от него возврата уплаченных за них средств. «Выход» из общества возможен только за счет отчуждения принадлежащих акционеру акций, что позволяет сохранять целостность капитала компании.

7. Акционер обладает как имущественными, так и личными правами. В случае если контрольный пакет акций аккумулируется в руках одного мажоритарного акционера, миноритарные акционеры не могут оказывать влияние на управление обществом. И тем самым не имеют возможности реализовать свои права в части управления обществом.

8. Все акции акционерного общества, при его учреждении, должны быть распределены среди его учредителей в соответствии с договором о создании акционерного общества. Если имеется только один учредитель - все акции должны быть приобретены этим единственным учредителем ${ }^{17}$.

9. Акционеры не отвечают по обязательствам общества и несут риск убытков в размере стоимости приобретенных ими акций. Из анализа ст. 36 Закона «Об акционерных обществах» можно видеть, что акции имеют номинальную и продажную стоимость. Продажная стоимость акций определяется советом директоров и, как правило, является

15 п.1 ст. 2 Закона «Об акционерных обществах»

16 В юридической литературе отсутствует легальное определение понятия имущество. Под имуществом принято понимать вещи, включая деньги и ценные бумаги, иное имущество, в том числе имущественные права; работы и услуги; охраняемые результаты интеллектуальной деятельности и приравненные к ним средства индивидуализации (интеллектуальная собственность); нематериальные блага.

17 П.3.1.1 Приказа ФСФР от 25 января 2007 г. № 07-4/пз-н «Об утверждении стандартов эмиссии ценных бумаг и регистрации проспектов ценных бумаг» / Бюллетень нормативных актов федеральных органов исполнительной власти. - 2007. - № 25. выше их номинальной стоимости, что позволяет кредиторам рассчитывать на большую сумму.

Кроме того, следует отметить, что на правовой статус акционерных обществ распространяются общие нормы о юридических лицах (§1 гл.4 ГКРФ), организациях (ч.ІІ п.2 ст.48 ГКРФ), коммерческих организациях (ст.50 ГКРФ), хозяйственных обществах (§2 гл.4 ГКРФ). Выделим наиболее важные из них.

1. Организационное единство юридического лица - это правовая конструкция, которая определяет систему внутренних организационных связей, обеспечиваемых, с формальной стороны, наличием учредительных документов во внешнем гражданском обороте, посредством воли и волеизъявления органов юридического лица, а также комплексом индивидуализирующих его элементов.

В содержание признака организационного единства входят следующие обязательные элементы:

- воля и волеизъявление юридического лица;

- формальное выражение внутреннего единства в учредительных документах юридического лица;

- органы, формирующие внутреннюю структуру организации;

- формы индивидуализации юридического лица, являющиеся его внешним проявлением ${ }^{18}$.

2. Экономический признак «выражается в имущественной обособленности юридического лица. Если организационное единство необходимо для объединения множества лиц в одно коллективное образование, то обособленное имущество создает материальную базу деятельности такого образования. Любая практическая деятельность немыслима без соответствующих инструментов: предметов техники, знаний, наконец, просто денежных средств. Объединение этих инструментов в один имущественный комплекс, принадлежащий данной организации и отграничение его от имущества, принадлежащего другим лицам, и называется имущественной обособленностью юридического лица» ${ }^{19}$.

Особенность содержащегося в ст. 48 ГК РФ правила заключается в том, что в нем прямо указаны те правовые формы, в которых может быть выражено имущественное обособление юридического лица: а) право собственности; б) право хозяйствен-

\footnotetext{
18 См.: Забарацкая Л. А. Организационное единство в системе обязательных признаков юридического лица: Дис. ... канд. юрид. наук. - Хабаровск, 2003.

19 См.: Свистунова Т.В. Гражданское право (общая часть). Гражданские правоотношения / Сайт цифровых учебно-методических материалов ВГУЭС http://abc.vvsu.ru/
} 
ного ведения; в) право оперативного управления.

3. Материально-правовой признак, означающий способность самостоятельно выступать в гражданском обороте от своего имени, то есть способность от своего имени приобретать, иметь и осуществлять имущественные, и личные неимущественные права, и нести обязанности, а также самостоятельно нести имущественную ответственность по своим обязательствам. ${ }^{20}$

4. Процессуально-правовой признак. Данный признак, «выражая наиболее непосредственно специфику юридического лица» ${ }^{21}$, заключается в том, что юридические лица от своего имени могут приобретать и осуществлять имущественные и личные неимущественные права, нести обязанности, быть истцами и ответчиками в суде. Признак выступления в обороте от собственного имени (с использованием собственного наименования) является следствием трех вышеназванных признаков ${ }^{22}$. «Это - итоговый признак юридического лица и одновременно та цель, ради которой оно и создается. Наличие организационной структуры и обособленного имущества, на котором базируется самостоятельная ответственность, как раз и позволяют ввести в гражданский оборот новое объединение лиц и капиталов - нового субъекта права» ${ }^{23}$.

«Акционерная форма предпринимательской деятельности стала одной из самых распространенных форм хозяйствования, глубоко вошла в механизм экономических преобразований в России и оказывает существенное влияние на его развитие» ${ }^{24}$.Но, как и любая форма объединения капитала, акционерные общества имеют, как преимущества, так и недостатки. Из наиболее важных преимуществ акционерного общества по сравнению с другими организационно-правовыми формами можно назвать:

1. Создание крупного капитала за счет объединения разрозненных средств в единую денежную массу. Мобилизация капитала возможна посред-

20 См.: Гражданское право / Отв. ред. В.П. Мозолин, А.И. Масляев. - М., 2004. - С.62.

${ }^{21}$ См.: Иоффе О.С. Советское гражданское право. - Л., 1958. - C. 105.

22 См.: Гражданское право Российской Федерации / Под. ред. О.Н. Садикова. - М., 2006. - С. 76.

23 См.: Гражданское право в 3 т. Т 1. / Под ред. А.П. Сергеева и Ю.К. Толстого. - М., 2005. - С. 121.

24 См.: Мамай В. И. К понятию и признакам акционерного общества // Государство и право. - 1996. - № 11. ством дополнительной эмиссии акций.

2. Неделимость и неприкосновенность капитала общества. По общему правилу, акции не предоставляют ее владельцу права на возврат внесенного вклада.

3. Упрощенная процедура передачи прав собственности на акции. Акции нормально функционирующих обществ имеют высокую оборачиваемость, ликвидность и возвратность активов ${ }^{25}$.

4. Анонимность участников акционерного общества.

5. Акционеры не отвечают по обязательствам общества и несут риск убытков, связанных с его деятельностью, в пределах стоимости принадлежащих им акций, в том числе, в пределах их неоплаченной стоимости. Акционерное общество, как юридическое лицо и самостоятельно хозяйствующий субъект, само отвечает перед своими кредиторами принадлежащим ему имуществом (п. 1 ст. 2; п. 1 ст. 3 Закона «Об акционерных обществах) $)^{26}$.

6. Возможность осуществления контроля за финансово-хозяйственной деятельностью со стороны акционеров при помощи ревизионной комиссии. В акционерном обществе формирование ревизионной комиссии является обязательным, независимо от количества акционеров. Даже, если в акционерном обществе все $100 \%$ акций принадлежат одному акционеру, он обязан в соответствии с п. 1 ст. 85 ФЗ «Об акционерных обществах» сформировать этот орган контроля ${ }^{27}$.

7. Неограниченное количество акционеров в открытых акционерных обществах.

8. Право акционеров на активы общества в случае его ликвидации. В случае ликвидации, после погашения всех видов кредиторской задолженности, активы общества делятся между его акционерами пропорционально количеству принадлежащих им акций. В акционерном обществе владельцы акций различных типов имеют различные привилегии в очередности распределения имущества (п. 1 и 2 ст. 23 Ф3 «Об акционерных обществах»).

Как мы можем видеть, акционерное общество является самой сложной организационно-правовой формой, отличается большим количеством

\footnotetext{
25 См.: Петражицкий Л.И. Акции, биржевая игра и теории экономических кризисов. Т.1. - СПб., 1911.

26 См.: Шиткина И.С. Правовое обеспечение деятельности акционерного общества. - М., 1997. - С. 18.

27 См.: Колтунов И.В. Чем должны заниматься корпоративщики // Акционерное общество: вопросы корпоративного управления. - 2008. - № 2.
} 
участников и, следовательно, возможностью концентрации большего капитала, более сложной структурой органов управления, а также обязанностью публичного ведения дел.

Одним из ключевых компонентов эффективной работы акционерного общества является деятельность органов управления и контроля, поскольку именно работа руководящих органов определяет результативность корпоративных решений, обеспечивает надлежащий уровень контроля над деятельностью менеджмента и устойчивость развития компании.

Для целей проведения данного исследования, представляется целесообразным рассмотреть существующие способы управления акционерными обществами, выделить некоторые наиболее существенные недостатки системы управления и предложить возможные способы их решения.

Управление акционерными обществами имеет своеобразные организационные формы. Для руководства текущей деятельностью общества формируются органы:

1. Коллективные, имеющие в своем составе лиц, не входящих в состав работников данной организации, но участвующие в принятии решений с правом решающего голоса (общее собрание акционеров);

2. Коллегиальные органы - организационно и юридически оформленные группы лиц, наделенные определенной компетенцией, включающей юридически властные полномочия (совет директоров, дирекция, правление и т.п.);

3. Единоличные (п. 3 ст. 103 Гражданского кодекса РФ) - директор, генеральный директор, председатель и др.

Центральное место в руководстве деятельностью акционерным обществом занимает совет директоров. В соответствии с п. 1 ст. 65 Федерального закона «Об акционерных обществах» в компетенцию совета директоров общества входит решение вопросов общего руководства деятельностью общества, за исключением вопросов, отнесенных к компетенции общего собрания акционеров. Так как совет директоров обладает большими полномочиями по руководству деятельностью акционерного общества, то вопрос правового статуса, обязанностей и ответственности членов совета директоров, на наш взгляд, является наиболее важным для создания эффективного органа управления на предприятии.

Одной из проблем корпоративного управления, является вопрос о профессиональных качествах членов совета директоров. В законода- тельстве не содержатся требования и критерии к профессиональным качествам, опыту и деловой репутации членов совета директоров. И достаточно часто на руководящих должностях оказываются директора, не имеющие высшего образования, ранее судимые, замешанные в разного рода махинациях, не знающие специфики работы предприятия и, следовательно, не способные эффективно организовать работу предприятия.

Закрепление квалификационных требований к членам совета директоров на уровне закона и внутренних документов общества способно оказать положительное влияние на развитие корпоративного управления и позволит минимизировать риски, связанные с участием в управлении обществом некомпетентных людей, а, следовательно, и риски возникновения у общества убытков, являющихся следствием подобного управления.

В связи с этим, считаем целесообразным внести изменения в п.1 ст. 66 Федерального закона «Об акционерных обществах», дополнив его абзацем следующего содержания:

1. Членом совета директоров (наблюдательного совета) общества может быть избрано лицо, отвечающее квалификационным требованиям, предусмотренным настоящим федеральным законом и уставом общества.

2. Членом совета директоров (наблюдательного совета) общества может быть лицо: имеющее высшее образование, удостоверенное дипломом государственного образца; обладающее опытом профессиональной деятельности не менее двух лет руководителем отдела, или иным подразделением организации, или опыт работы не менее пяти лет в сфере основного вида деятельности общества; не совершавшее в течение двух лет, предшествовавших дню проведения общего собрания акционеров по выбору кандидата в совет директоров общества, административного правонарушения в области торговли и финансов, установленного вступившим в законную силу постановлением органа, уполномоченного рассматривать дела об административных правонарушениях; не имеющее судимости; отвечающее иным основаниям, установленным федеральными законами.

В настоящее время в корпоративном управлении можно видеть тенденцию к возрастанию ответственности членов совета директоров за убытки, причиненные акционерному обществу. В судебной практике не редкими являются иски акционеров к членам совета директоров за убытки общества, но в силу того, что доказать факт убыт- 
ков и их размер, в частности, по данной категории споров в судах чрезвычайно сложно, судебная практика все еще крайне бедна делами, касающимися ответственности директоров и, практически не встретить дел, которые заканчивались бы решением о взыскании с директора убытков ${ }^{28}$.

Причиной предъявления иска могут быть ошибочные действие при управлении компанией, неполное раскрытие информации, ошибки, неточности, допущенные в финансовой отчетности, инвестиционных декларациях и проспектах эмиссии, несоблюдение порядка проведения крупных сделок, и т.п. Одним из способов решения обозначенной нами проблемы, на наш взгляд, является страхование ответственности директоров и руководителей.

В последние годы, в связи с выходом российских компаний на иностранные биржи, все более популярным становится страхование профессиональной ответственности членов совета директоров $\mathrm{D} \& 0$ (D\&0, directors and officers liability insurance - страхование ответственности директоров и руководителей), так как оно является обязательным условием для IPO, или размещения депозитарных расписок. Но, в российском законодательстве существует ряд проблем, препятствующих развитию страхования ответственности директоров.

Так, например, в Федеральном законе «Об акционерных обществах» отсутствуют положения о страховании ответственности директоров. На практике некоторые компании применяют данный вид страхования, но при этом, у них возникают определенные сложности. Например, страхование ответственности осуществляется за счет чистой прибыли общества и не относится на себестоимость, хотя данные расходы связаны с обеспечением деятельности совета директоров. А при наступлении страхового случая выплаты включаются в состав доходов членов совета директоров и облагаются подоходным налогом.

На основании вышеизложенного, в целях развития корпоративного управления и института страхования ответственности в Российской Федерации, по нашему мнению, было бы целесообразно дополнить ст. 64 Федерального закона «Об акционерных обществах» пунктом 3 изложив его в сле-

28 См.: Постановление Северо-Кавказского округа от 27 мая 2003 г. № Ф08-1555/2003 (убытки причинены акционерному обществу) и Постановление Федерального арбитражного суда Восточно-Сибирского округа от 22 сентября 2005 г. № А33-25557/04-С1-Ф02-4683/05-С2 (убытки причинены обществу с ограниченной ответственностью). дующей редакции:

3. По решению общего собрания акционеров ответственность членов совета директоров (наблюдательного совета) общества в период исполнения ими своих обязанностей должна быть застрахована за счет средств общества.

В России роль государства, как акционера и собственника акционерных компаний, очень велика. Государство является одним из крупнейших акционеров, помимо большого числа предприятий и организаций, полностью принадлежащих государству, оно сохранило право собственности на акции стратегически важных предприятий.

Основными способами участия органов государственной власти в управлении акционерными обществами являются:

- назначение уполномоченного представителя; - передача акций доверительному управляющему.

Государство управляет принадлежащими ему акциями через своих представителей. Роль представителей государства в процессе государственного регулирования деятельности акционерных обществ с государственным капиталом весьма значительна. Представитель, с одной стороны, призван защищать интересы государства, а с другой стороны, активный член органов управления общества, участвующий в выработке политики компании. Эффективность функционирования указанных акционерных обществ в большой степени зависит от компетенции и ответственность представителей государства.

На основании Федерального закона от 21 декабря 2001 г. «0 приватизации государственного и муниципального имущества в Российской Федерации» ${ }^{29}$ Правительство РФ, органы государственной власти субъектов РФ, органы местного самоуправления, при преобразовании государственных и муниципальных унитарных предприятий в открытые акционерные общества, либо при принятии решений о продаже находящихся в государственной или муниципальной собственности акций таких обществ, могут принимать решения об использовании в отношении них специального права на участие соответственно России, ее субъектов и муниципальных образований в управлении ими. В таком случае они назначают представителей государства и муниципальных органов в совет директоров (наблюдательный совет) и ревизионную комиссию открытого акционерного общества.

Представителями могут быть назначены ра-

29 См.: Собрание законодательства РФ. - 2002. - № 4. CT. 251. 
ботники, находящиеся на руководящих должностях федеральных органов исполнительной власти, органов исполнительной власти субъектов РФ, крупных хозяйственных структур, а также, иные лица, которые осуществляют свою деятельность на основании положения, утвержденного Правительством РФ ${ }^{30}$. Обеспечивается в установленном законом порядке избрание этих лиц в совет директоров акционерного общества.

На ведомственном уровне основные полномочия в этой сфере отнесены к ведению Федерального агентства по управлению государственным имуществом. Оно, также как и Правительство, назначает представителей государства в акционерные общества, определяет их права и обязанности, дает письменные директивы, обязывающие представителей государства действовать в публичных интересах ${ }^{31}$. Регламентация имущественных интересов Российской Федерации отнесена к ведению федеральных агентств, федеральных министерств и федеральных служб, которые осуществляют отдельные полномочия по управлению акциями открытых акционерных обществ в случаях, специально предусмотренных указами Президента РФ, или постановлениями Правительства РФ. Так, например, Минэкономразвития России устанавливает обязательные требования к коммерческой деятельности указанных акционерных обществ ${ }^{32}$.

Использование по инициативе органа исполнительной власти специального права, означает ограничение правомочий акционерного общества. Все важнейшие функции внутриорганизационного

30 См.: Постановление Правительства от 3 декабря 2004 г. № 738 «Об управлении находящимся в федеральной собственности акциями открытых акционерных обществ и использовании специального права на участие Российской Федерации в управлении открытыми акционерными обществами «золотой акции» // Собрание законодательства РФ. 2004. - № 50. - Ст. 5073.

31 Подпункт 5.29 Положения о Федеральном агентстве по управлению государственным имуществом, утвержденного постановлением Правительства Российской Федерации от 5 июня 2008 г. № 432.

32 К ведению Минэкономразвития России отнесены полномочия по установлению перечня и порядка определения показателей экономической эффективности коммерческой деятельности указанных открытых акционерных обществ. Нормативно-правовые акты Минэкономразвития, устанавливающие такие нормы, обязательны для исполнения $\mathrm{OAO}$ (подп. 5.2.1. Положения о Министерстве экономического развития Российской Федерации, утвержденного постановление Правительства Российской Федерации от 5 июня 2008 г. № 437 управления могут приниматься открытым акционерным обществом по согласованию и при непосредственном участии представителей Российской Федерации, которые вправе отклонить предложения по ряду существенных вопросов. Представители имеют право вето при принятии общим собранием акционерного общества решения о внесении изменений и дополнений в устав, или об утверждении его в новой редакции; о ликвидации общества, назначении ликвидационной комиссии и об утверждении ликвидационного баланса ${ }^{33}$; об изменении уставного капитала; о заключении определенных сделок, и т.д. Полномочия представителей Российской Федерации имеют доминирующее значение.

Среди существенных, на наш взгляд, недостатков института государственных представителей можно назвать:

1. Низкую оперативность принятия управленческих решений.

2. Отсутствие механизмов оценки профессиональных качеств и квалификации представителей, что в свою очередь приводит к назначению представителями лиц, не обладающих достаточной подготовкой для исполнения ими своих обязанностей.

3. Отсутствие у представителей хозяйственной инициативы, ответственного подхода к осуществлению своих функций.

4. Назначение одного служащего представителем сразу в несколько акционерных обществ.

5. Отсутствие системы стимулирования труда государственных представителей.

6. Отсутствие какой-либо ответственности за убытки предприятия.

Более перспективным, на наш взгляд, способом повышения эффективности деятельности акционерных обществ является привлечение к управлению государственными акциями доверительных управляющих. Отличительной особенностью данного способа участия государства в управлении обществом является то, что управление осуществляется не государственными служащими, а профессиональными менеджерами, работающими на условиях материальной заинтересованности и ответственности. Но и в законодательстве о доверительных управляющих содержится много пробелов.

Для повышения эффективности института до-

33 См.: В отдельных случаях предусматривается ведение института арбитражного управляющего (в условиях банкротства) и временной администрации для кредитных организаций с участием представителей государства. 
верительного управления государственными акциями, по нашему мнению, необходимо определить:

- порядок отбора, подготовки и оценки управляющих, проведение аттестационных экзаменов на право представлять государство в совете директоров;

- порядок постановки конкретных задач и закрепления в договоре с управляющим программы мероприятий по развитию предприятия;

- полномочия управляющих в зависимости от характера объекта управления;

- четкий порядок и механизм информирования государственного органа о промежуточных и итоговых результатах работы управляющего по реализации задач и мероприятий, определенных в договоре.

В целях совершенствования института представителей государства в акционерных обществах, по нашему мнению, было бы целесообразно внести в Положение «Об управлении находящимися в федеральной собственности акциями открытых акционерных обществ и использовании специального права на участие Российской Федерации в управлении открытыми акционерными обществами («золотой акции»)» утвержденное Постановлением Правительства РФ от 3 декабря 2004 г. № 738 следующие поправки:

Дополнить пункт 21 третьим и четверым абзацами, изложив их в следующей редакции: Физическое лицо может быть назначено представителем Российской Федерации в совете директоров не более двух акционерных обществ.

Представитель Российской Федерации не может быть представителем других акционеров (участников) в органах управления данного обществах.

Дополнить Положение пунктом 23, изложив его в следующей редакции: C представителями Российской Федерации в совете директоров и ревизионной комиссии акционерного общества заключается договор на представление интересов Российской Федерации в органах управления хозяйствующего общества (далее договор)

Договором устанавливаются:

А) срок действия договора;

Б) сроки, форма и порядок отчетности представителя;

В) ответственность представителя за неисполнение, или ненадлежащее исполнение своих обязанностей;

Г) порядок возмещения издержек, понесенных представителем в связи с осуществление им своих полномочий;

Д) размер и порядок выплаты вознаграждения представителю и иные условия.

Права, обязанности и ответственность представителя определяются правовым актом о назначении представителя, договором, настоящим Положением, иными нормативными правовыми актами Российской Федерации.

Представитель не несет ответственности за последствия решений, за которые он проголосовал, если голосование осуществлялось на основании письменных директив, полученных им в соответствии с настоящим Положением.

Дополнить Положение пунктом 24 изложив его в следующей редакции:

Полномочия представителя прекращаются в случаях:

1. Истечения срока действия договора о представлении интересов Российской Федерации в акционерном обществе;

2. Отказа физического лица от полномочий представителя;

3. Принятия правового акта о досрочном прекращении полномочий представителя;

4. В иных случаях, предусмотренных законодательством Российской Федерации.

Дополнить Положение пунктом 25, изложив его в следующей редакции: Правовой акт о досрочном прекращении полномочий представителя принимается в следующих случаях: неисполнение, или ненадлежащее исполнение договора; прекращение права собственности Российской Федерации на акции, или долю; наступление обстоятельств, препятствующих представителю осуществлять свои полномочия, в том числе, длительная командировка, увольнение государственного служащего, прекращение осуществления полномочий лищом, занимающим государственную должность, продолжительная болезнь.

1. Ликвидация, или реорганизация хозяйственного общества;

2. Передача акций, или доли в доверительное управление, или хозяйственное ведение;

3. В иных случаях, установленных законодательством Российской Федерации.

Таким образом, проведя анализ акционерных обществ как объекта управляющего воздействия государства можно сделать следующие выводы.

Акционерные общества обладают особыми отличительными признаками и преимущества по сравнению с другими организационно-правовы- 
ми формами, руководство деятельностью обществ может осуществляться как коллективными и коллегиальными органами управления, так и единоличными. Но сложившаяся система формирования управляющих органов акционерного общества требует серьезной переработки. Необходимо законодательно прописать квалификационные требования к членам совета директоров, предусмотреть возможность страхования профессиональной ответственности членов совета директоров за счет средств общества. Так же важно отметить, что сформированная на настоящий момент система участия государства в управлении акционерными обществами неэффективна и требует серьезной переработки.

Реформирование государственного участия в управлении акционерными обществами должно развиваться по пути увеличения административно-правовой составляющей в системе ответственности доверительных управляющих, с обязательным обеспечение возможности привлечения к ответственности должностных лиц органов государственной власти; строгим отбором кандидатов на должность доверительного управляющего и выплатой вознаграждения по результатам ежегодной финансовой отчетности общества. Предложенные нами поправки в акционерное законодательство способны повысить эффективность работы органов управления обществом и оказать положительное воздействие на развитие института представителей государства в акционерных обществах.

\section{Библиография:}

1. Сыродоева О.Н. Акционерное право США и России. Сравнительный анализ. - М.,1996. 10. Сусликов В.Н Функции государственного управления и экономика // Административное право Российской Федерации. Проблемные вопросы развития отрасли правовой системы и преподавания курса. - Новгород, 1999.

2. Костенников М.В., Куракин А.В., Павлюк А.В. К вопросу о понятии и методах государственного управления в административном праве // NB: Административное право и практика администрирования. - 2014. - 2. - С. 40 - 63. DOI: 10.7256/2306-9945.2014.2.11188. URL: http://www.e-notabene.ru/al/article_11188.html

3. Костенников М.В. К вопросу о некоторых актуальных проблемах административного права // NB: Административное право и практика администрирования. - 2013. - 4. - С. 71 - 95. DOI: 10.7256/2306-9945.2013.4.8840. URL: http:// www.e-notabene.ru/al/article_8840.html

\section{References (transliterated):}

1. Syrodoeva O.N. Aktsionernoe pravo SShA i Rossii. Sravnitel'nyi analiz. - M.,1996. 10. Suslikov V.N Funktsii gosudarstvennogo upravleniya i ekonomika // Administrativnoe pravo Rossiiskoi Federatsii. Problemnye voprosy razvitiya otrasli pravovoi sistemy i prepodavaniya kursa. - Novgorod, 1999.

2. Kostennikov M.V., Kurakin A.V., Pavlyuk A.V. K voprosu o ponyatii i metodakh gosudarstvennogo upravleniya v administrativnom prave // NB: Administrativnoe pravo i praktika administrirovaniya. - 2014. - 2. - C. 40 - 63. DOI: 10.7256/23069945.2014.2.11188. URL: http://www.e-notabene.ru/al/article_11188.html

3. Kostennikov M.V. K voprosu o nekotorykh aktual'nykh problemakh administrativnogo prava // NB: Administrativnoe pravo i praktika administrirovaniya. - 2013. - 4. - C. 71 - 95. DOI: 10.7256/2306-9945.2013.4.8840. URL: http://www.e-notabene.ru/ al/article_8840.html 